Research Article

\title{
Evaluation of the mutagenicity and antimutagenicity of Ziziphus joazeiro Mart. bark in the micronucleus assay
}

Marcelo Fabiano Gomes Boriollo ${ }^{1,2}$, Marielly Reis Resende ${ }^{4}$, Thaísla Andrielle da Silva ${ }^{1,2}$, Juliana Yoshida Públio ${ }^{2}$, Luiz Silva Souza ${ }^{1,2}$, Carlos Tadeu dos Santos Dias ${ }^{4}$, Nelma de Mello Silva Oliveira ${ }^{1,3}$ and João Evangelista Fiorini ${ }^{1,2}$

${ }^{1}$ Laboratório de Farmacogenômica e Biologia Molecular, Faculdade de Ciências Médicas, Universidade José do Rosário Vellano, Alfenas, MG, Brazil.

${ }^{2}$ Centro de Pesquisa e Pós-Graduação em Ciência Animal, Área de Patologia e Farmacologia Animal, Universidade José do Rosário Vellano, Alfenas, MG, Brazil.

${ }^{3}$ Laboratório de Ecotoxicologia e Microbiologia Ambiental, Faculdade de Tecnologia,

Universidade Estadual de Campinas, Limeira, SP, Brazil.

${ }^{4}$ Departamento de Ciências Exatas, Escola de Agricultura “Luiz de Queiroz”, Universidade de São Paulo, Piracicaba, SP, Brazil.

\begin{abstract}
The aim of this study was to evaluate the mutagenicity (clastogenicity/aneugenicity) of a glycolic extract of Ziziphus joazeiro bark (GEZJ) by the micronucleus assay in mice bone marrow. Antimutagenic activity was also assessed using treatments associated with GEZJ and doxorubicin (DXR). Mice were evaluated 24-48 $\mathrm{h}$ after exposure to positive (N-nitroso-N-ethylurea, NEU - 50 mg. $\mathrm{kg}^{-1}$ and DXR - $\left.5 \mathrm{mg} \cdot \mathrm{kg}^{-1}\right)$ and negative $(150 \mathrm{mM} \mathrm{NaCl})$ controls, as well as treatment with GEZJ (0.5-2 g. $\left.\mathrm{kg}^{-1}\right)$, GEZJ $\left(2 \mathrm{~g} \cdot \mathrm{kg}^{-1}\right)+$ NEU and GEZJ $\left(2 \mathrm{~g}^{-\mathrm{kg}^{-1}}\right)+$ DXR. There were no significant differences in the frequencies of micronucleated polychromatic erythrocytes in mice treated with GEJZ and GEJZ + DXR compared to the negative controls, indicating that GEZJ was not mutagenic. Analysis of the polychromatic:normochromatic erythrocyte ratio revealed significant differences in the responses to doses of $0.5 \mathrm{~g} \cdot \mathrm{kg}^{-1}$ and $1-2 \mathrm{~g} \cdot \mathrm{kg}^{-1}$ and the positive control (NEU). These results indicated no systemic toxicity and moderate toxicity at lower and higher doses of GEZJ. The lack of mutagenicity and systemic toxicity in the antimutagenic assays, especially for treatment with GEZJ + DXR, suggested that phytochemical compounds in Z. joazeiro bark attenuated DXR-induced mutagenicity and the moderate systemic toxicity of a high dose of $Z$. joazeiro bark $\left(2 \mathrm{~g} \cdot \mathrm{kg}^{-1}\right)$. Further studies on the genotoxicity of $Z$. joazeiro extracts are necessary to establish the possible health risk in humans and to determine the potential as a chemopreventive agent for therapeutic use.
\end{abstract}

Keywords: antimutagenicity, bone marrow, doxorubicin, micronucleus assay, mutagenicity, Zizyphus joazeiro Mart. (raspa-de-Juá).

Received: October 3, 2013; Accepted: March 17, 2014.

\section{Introduction}

Many species of medicinal plants, such as Amburana cearensis, Anadenanthera colubrina, Mentha x villosa, Myracrodruon urundeuva, Plectranthus amboinicus, Ruta graveolens, Ximenia americana and Ziziphus joazeiro, are widely used by communities in the Brazilian Caatinga to treat a large spectrum of clinical conditions ranging from diseases requiring palliative care to general aches, e.g., bronchitis, sinusitis, rhinitis, nasal congestion, headaches,

Send correspondence to Marcelo Fabiano Gomes Boriollo. Laboratório de Farmacogenômica e Biologia Molecular, Faculdade de Ciências Médicas \& Centro de Pesquisa e Pós-Graduação, Universidade José do Rosário Vellano, Rodovia MG 179, km 0, Campus Universitário, 37130-000 Alfenas, MG, Brazil. E-mail: marcelo.boriollo@unifenas.br. flu, fever, expectorant, colic, hypertension, thrombosis, indigestion, intestinal dysfunction, liver and kidney problems, infectious and inflammatory processes and pain in general (Cartaxo et al., 2010). Ziziphus joazeiro Mart. (Rhamnaceae) is a native Brazilian tree resistant to dry environments (Cartaxo et al., 2010). This species is an important source of water and food for animals in arid habitats (Braga, 1960; Cruz, 1985; Nunes et al., 1987).

A phytochemical analysis of $Z$. joazeiro Mart. has shown that the leaf epicuticular wax is rich in $n$-alkanes (78.6\%), very efficient compounds for impermeabilizing the leaf surface, and triterpenoids (Oliveira et al., 2003). A similar analysis of a dichloromethane extract of $Z$. joazeiro Mart. bark identified triterpenoids with weak antibacterial activity (e.g., betulinic, alphitolic and ursolic acids) and re- 
markable activity against Staphylococcus epidermidis [e.g., betulinic acid ester derivatives such as 7 $73-(4-$ hydroxy-benzoyloxy), 7 $\beta$-(4-hydro-3-methoxy-benzoyloxy) and 27-(4-hydroxy-3-methoxy-benzoyloxy)] (Schuhly et al., 1999). Ziziphus joazeiro Mart. bark also contains an abundance of saponins that have been used as toothpastes, with aqueous extracts showing antimicrobial action against bacteria (planktonic cells and artificial biofilms) related to dental caries and periodontal diseases (Alviano et al., 2008). Other popular therapeutic applications of $Z$. joazeiro Mart. include the treatment of dandruff, rheumatism, flu, fever, chronic bronchitis, gastric ulcers, indigestion, heartburn and headaches (Schuhly et al., 1999; Cartaxo et al., 2010). In addition, experimental studies have identified potential antifungal (Cruz et al., 2007), antibacterial (Schuhly et al., 1999; Alviano et al., 2008; Leal et al., 2010), antioxidant (Alviano et al., 2008) and antipyretic (Nunes et al., 1987) activities, as well as low toxicity (Alviano et al., 2008).

Biologically active compounds have been recognized for their pharmacological properties, but many of them are of limited therapeutic use because of their toxicological, carcinogenic and mutagenic properties (Ames, 1983; Konstantoupoulou et al., 1992; Tavares, 1996). The analysis of genotoxicity is a major aspect of drug development since most pharmaceutical companies evaluate the potential of a new therapeutic agent based on its genotoxicity in vitro and in vivo (Purves et al., 1995). In this context, the screening of popularly used plants and their isolated components for mutagenic activity is necessary and important for establishing adequate control measures. This screening can also provide insights into the mechanisms involved in the biological effects of plants used as therapeutic agents (Varanda, 2006).

As far as genotoxicity studies are concerned, the in vivo micronucleus (MN) assay in rodent bone marrow is a crucial part of the battery of tests used to identify hazardous mutagens (Mateuca et al., 2006). This assay is especially suited for assessing mutagenic hazards because it contemplates various factors, such as in vivo metabolism, pharmacokinetics and DNA repair mechanisms, even though these processes vary among species and tissues and have different genetic endpoints (OECD, 1997a,b; Ribeiro et al., 2003). Since bone marrow erythroblasts develop into polychromatic erythrocytes (PCEs), i.e., cells generated by extrusion of the main nucleus, micronuclei may remain in an otherwise anucleated cytoplasm. Consequently, the frequency of micronucleated polychromatic erythrocytes (MNPCEs) has been the principal endpoint for MN assays. The measurement of MNPCEs in peripheral blood is possible in any species in which the spleen does not remove micronucleated erythrocytes, or that is sufficiently sensitive to agents that cause structural or numerical chromosomal aberrations. An increase in the frequency of MNPCEs in treated animals, i.e., a positive result, indicates that a substance can cause the formation of micronuclei through chromosomal damage or damage to the mitotic apparatus of erythroblasts. On the other hand, a negative result implies that the test substance does not cause micronucleus formation in immature erythrocytes. The number of normochromatic erythrocytes (NCEs) in peripheral blood that contain micronuclei for a given number of mature erythrocytes can also be used as the endpoint of this assay (OECD, 1997c; Ribeiro et al., 2003). Several studies have used the mammalian in vivo $\mathrm{MN}$ assay to understand the mutagenic effects induced by phytotherapeutics and foods (Indart et al., 2007; Venkatesh et al., 2007; Chandrasekaran et al., 2011; Silva et al., 2011; Alves et al., 2012).

Although several studies have examined the potential therapeutic effectiveness of $Z$. joazeiro Mart., there has been no systematic investigation of the genotoxic and mutagenic effects of this plant. In this work, we examined the mutagenic effects of a glycolic extract of $Z$. joazeiro Mart. bark as part of a wider study on the genotoxic potential of herbal extracts. The effect of the maximum permissible concentration of $Z$. joazeiro Mart. on the mutagenicity of doxorubicin (DXR) in mouse bone marrow, i.e., its antimutagenic activity, was also examined.

\section{Material and Methods}

\section{Raw material and sample preparation}

A glycolic extract of $Z$. joazeiro bark (GEZJ) was purchased commercially and stored according to the manufacturer's recommendations (AKSY Comercial Ltda., São Bernardo do Campo, SP, Brazil). Aliquots $(1.5 \mathrm{~L})$ of this extract were submitted to solvent removal proceedings by rotary evaporation (40 rpm) (Rotavapor model R-215) coupled to a bath heating system maintained at $50-60{ }^{\circ} \mathrm{C}$ (Bath Heating model B-491), a vacuum pump (vacuum of 500 mm Hg; Vacuum Pump V-700 with Automatic Vacuum Controller V-855), a water recirculator (Recirculator Chiller F-100) and an evaporation bottle (Büchi Labortechnik AG, Switzerland). The final product was transferred to a $1 \mathrm{~L}$ reaction bottle $\left(\mathrm{SCHOTT}^{\circledR}{ }^{\circledR}\right.$ DURAN $\left.^{\circledR}\right)$ and kept at $-20^{\circ} \mathrm{C}$ for $24 \mathrm{~h}$ in order to evaluate the freezing of the final product and the efficacy of solvent evaporation (Agência Nacional de Vigilância Sanitária (ANVISA) (2010)). Aliquots $(40 \mathrm{~mL})$ of this final product were transferred to penicillin-type glass vials $(50 \mathrm{~mL})$ and lyophilized (Lyophilizer model Alpha 1-2 LDPlus, Martin Christ Gefriertrocknungsanlagen GmbH, Germany) and the dry mass were measured (Electronic Analytical Balance AUW-220D, Shimadzu Corp., Kyoto, Japan). Aqueous solutions of the lyophilized product were prepared in type 1 water at twice the final concentration, sterilized by filtration (Millipore Corporation, hydrophilic Durapore ${ }^{\circledR}$ PVDF, $0.22 \mu \mathrm{m}, \pm 47 \mathrm{~mm}$, cat. no. GVWP 04700 ) and stored in sterile polypropylene tubes $(50 \mathrm{~mL})$ at $-70{ }^{\circ} \mathrm{C}$ until used. 


\section{In vivo assays}

Healthy, heterogeneous, young adult male and female Swiss mice (Unib:SW) 7-12 weeks old (pubescent period) weighing 30-40 g (weight variation among mice of each sex was $<20 \%$ of the mean weight) were provided by CEMIB (Centro Multidisciplinar para Investigação Biológica - UNICAMP) and erythrocytes from the bone marrow of these mice were used in the MN assay (Collaborative Study Group for the Micronucleus Test (CSGMT), 1986; Chorilli et al., 2007).

Animals of the same sex were housed in polypropylene boxes in an air-conditioned environment to $22 \pm 3{ }^{\circ} \mathrm{C}$, with a relative air humidity of $50 \% \pm 20 \%$ and a $12 \mathrm{~h}$ light/dark cycle. The mice were fed commercial rodent chow (Purina ${ }^{\circledR}$ Labina, Nestlé Purina Pet Care Company) and water ad libitum, and were acclimated to laboratory conditions for seven days prior to use in the experiments. At the end of this period, each mouse was weighed and then received $2 \mathrm{~mL}$ of liquid (containing the desired test agent) per $100 \mathrm{~g}$ body weight.

All animals were properly identified by numerical markings on their tails to ensure continuity of the records and reliable interpretation of the results throughout the study (OECD, 1997c). After the period of treatment, the mice were euthanized by inhalation of carbon dioxide in adapted acrylic chambers as described in the Report of the American Veterinary Medical Association panel on euthanasia (Beaver et al., 2000). This study was done in accordance with the Universal Declaration of Animal Rights (UNESCO, 1978), the ethical principles for animal experimentation established by the Brazilian Society of Labora-
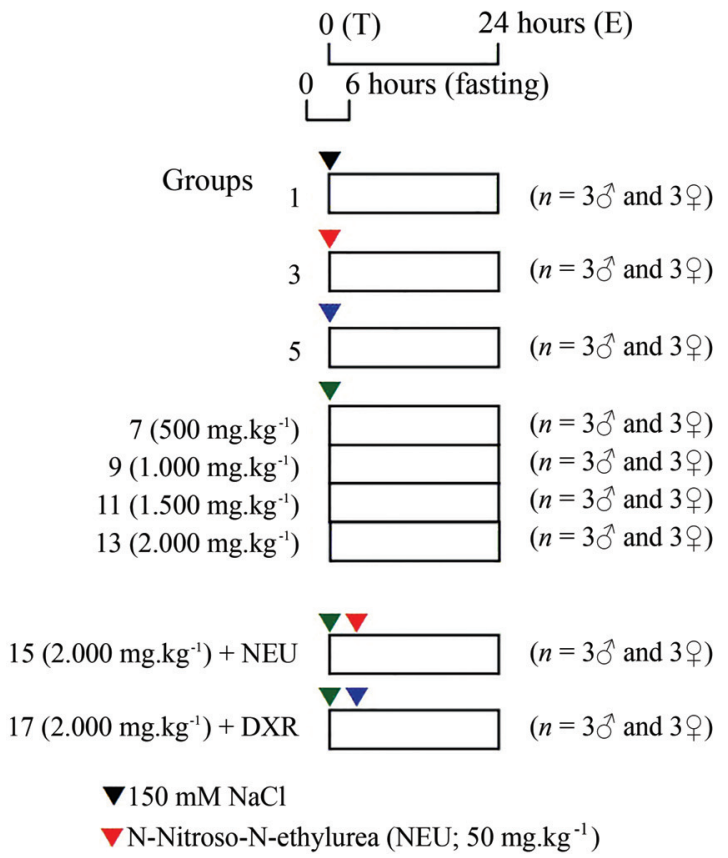

tory Animal Science (SBCAL - Sociedade Brasileira de Ciência em Animais de Laboratório), the Brazilian Environmental Crimes Law (Law no. 9.605, February 12, 1998), the Brazilian standards for Didactic-Scientific Practice of Vivisection of Animals (Law no. 6.638, May 8, 1979), and was approved by the Committee for Ethics in Research Involving Animals at UNIFENAS (CEPEAU Protocol no. 04A/2008).

\section{Experimental groups}

The experimental groups of mice ( 3 males and 3 females each) were assessed $24 \mathrm{~h}$ and $48 \mathrm{~h}$ after a single treatment administered by gavage (Figure 1). The mutagenic activity of GEZJ was assessed in mice that received doses of $0.5-2 \mathrm{~g} . \mathrm{kg}^{-1}$ (groups 7-14) and the antimutagenic activity was assessed in mice that received NEU $\left(50 \mathrm{mg} \cdot \mathrm{kg}^{-1}\right)+$ GEZJ (2 g. $\left.\mathrm{kg}^{-1}\right)$ (groups 15 and 16) and DXR (5 mg. $\left.\mathrm{kg}^{-1}\right)+$ GEZJ (2 g. $\left.\mathrm{kg}^{-1}\right)$ (groups 17 and 18). The doses of GEZJ were chosen based on previous acute toxicity experiments in mice that yielded $\mathrm{LD}_{50}$ values of $2.0-3.5 \mathrm{~g} / \mathrm{kg}$ for several plant extracts, including $Z$. joazeiro (Alviano et al., 2008). Negative controls (groups 1 and 2: $150 \mathrm{mM} \mathrm{NaCl}$ in type 1 water) and positive controls (groups 3 and 4: $50 \mathrm{mg} \cdot \mathrm{kg}^{-1}$ of NEU; groups 5 and 6: $5 \mathrm{mg} \cdot \mathrm{kg}^{-1}$ of DXR) were also included as single treatments administered by gavage $(\mathrm{NaCl})$ and intraperitoneally (NEU and DXR) (OECD, 1997c).

\section{Processing of bone marrow}

MN assays using bone marrow erythrocytes were done $24 \mathrm{~h}$ and $48 \mathrm{~h}$ after treatment, using previously described methodology (Schmid, 1976; Zambrano et al.,

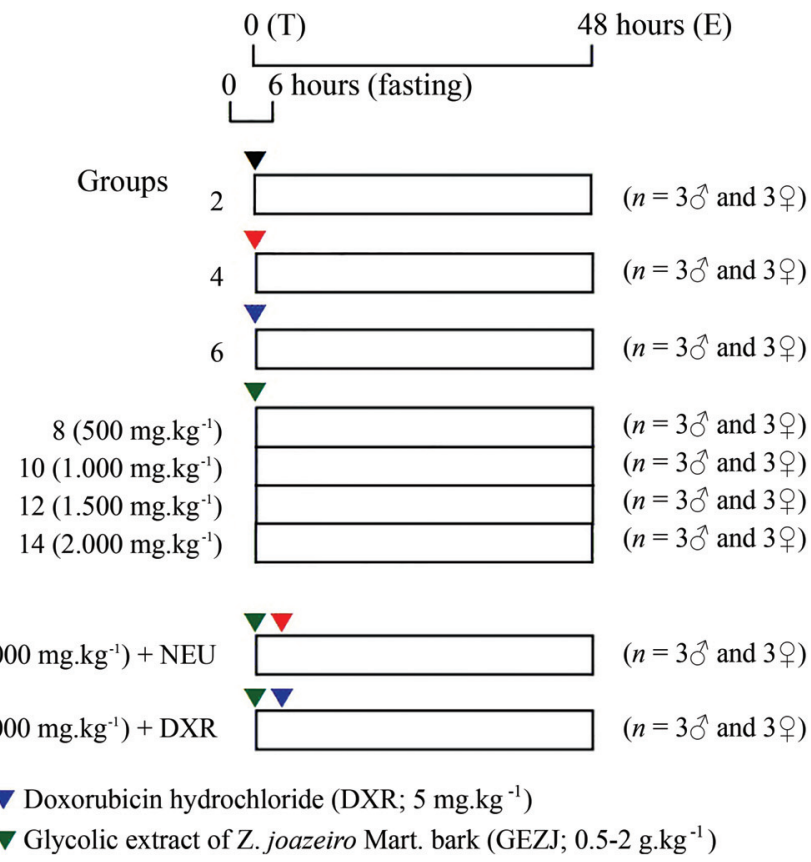

Figure 1 - Experimental protocol for assessing the mutagenic and antimutagenic activity of a glycolic extract of Z. joazeiro bark. T - treatment, E - euthanasia and $n$ - number of mice. 
1982). Shortly after euthanasia, the femora were surgically and aseptically removed and the mice were appropriately discarded. Each femur was sectioned at the proximal end and the contents of the spinal canal were washed with $1.5 \mathrm{~mL}$ of $150 \mathrm{mM} \mathrm{NaCl}$ and transferred to a $15 \mathrm{~mL}$ centrifuge tube. This material was resuspended with a Pasteur pipette to ensure a homogenous distribution of bone marrow cells. The suspension was then centrifuged at 1,000 rpm (Bench centrifuge, model NT 810, Nova Técnica Ind. e Com. de Equip. para Laboratório Ltda., Piracicaba, SP, Brazil) for $5 \mathrm{~min}$. The supernatant was discarded and the resulting pellet was resuspended in $500 \mu \mathrm{L}$ of $150 \mathrm{mM} \mathrm{NaCI}$ solution added $4 \%$ formaldehyde. The slides (two per animal) were prepared by smearing, dried at room temperature for $24 \mathrm{~h}$ and stained with Leishman's eosin methylene blue dye [pure dye for $3 \mathrm{~min}$ followed by diluted dye in distilled water $(1: 6)$ for $15 \mathrm{~min}$ ] to differentiate polychromatic erythrocytes (PCEs) from monochromatic erythrocytes (NCEs).

PCEs were observed by light microscopy (Nikon Eclipse E-200 microscope) at a magnification of 1000x, counted (at least 2000 anucleated polychromatic erythrocytes per animal) with the aid of a digital cell counter (Contador Diferencial CCS02, Kacil Indústria e Comércio Ltda., PE, Brazil) and photographed using an 8.1 Megapixel Digital Camera (DC FWL 150). The number of PCEs, the number and frequency of MNPCEs and the ratio of polychromatic to monochromatic erythrocytes (PCE/NCE) were determined.

\section{Statistical analysis}

The data from the MN assay were analyzed by oneway analysis of variance (ANOVA) using a $9 \times 2 \times 2$ (treatment $\mathrm{x}$ gender $\mathrm{x}$ time) factorial scheme followed by multiple comparisons with the Tukey test $(\alpha=0.05)$. All analyses were done using $\mathrm{SAS}^{\circledR}$ version 9.2 computer software.

\section{Results and Discussion}

Ziziphus joazeiro Mart. has been popularly used to treat dandruff, rheumatism, flu, fever, chronic bronchitis, gastric ulcers, indigestion, heartburn and headaches and to clean teeth (Schuhly et al., 1999; Cartaxo et al., 2010). In addition, Z. joazeiro has potential antifungal (Cruz et al., 2007), antibacterial (Schuhly et al., 1999; Alviano et al., 2008; Leal et al., 2010), antioxidant (Alviano et al., 2008) and antipyretic (Nunes et al., 1987) activities, as well as low toxicity (Alviano et al., 2008). This information partly supports the popular use of $Z$. joazeiro for certain treatments and agrees with ethnopharmacological studies designed to select plants for bioactivity screening (Cruz et al., 2007). In contrast, few studies have examined the mutagenic and antimutagenic effects of $Z$. joazeiro Mart.
In the present study, the number and frequency of MNPCEs and the PCE/NCE ratios in mouse bone marrow were analyzed in mutagenic and antimutagenic assays of a glycolic extract of $Z$. joazeiro bark (Table 1 and Figure 2). Analysis of the MNPCEs revealed no significant differences between the $24 \mathrm{~h}$ and $48 \mathrm{~h}$ results for the negative $(\mathrm{NaCl})$ and positive (DXR and NEU) controls. However, there were significant differences $(p<0.05)$ between the negative and positive controls at the two time intervals. There were no differences between the negative controls and the treatments with GEJZ $\left(0.5-2 \mathrm{~g}^{\mathrm{kg}}{ }^{-1}\right)$ or with GEJZ $\left(2\right.$ g.kg $\left.{ }^{-1}\right)+$ DXR $\left(5\right.$ mg.kg $\left.{ }^{-1}\right)$ : these responses showed no dose or time dependence, but varied between male and female mice. Mice treated with GEJZ $\left(2 \mathrm{~g}^{\mathrm{kg}}{ }^{-1}\right)+\mathrm{NEU}(50$ $\left.\mathrm{mg} \cdot \mathrm{kg}^{-1}\right)$ had intermediate values $(n$ and \%) that differed significantly from the negative and positive controls. These results suggest absence of mutagenicity (clastogenicity and/or aneugenicity) for GEZJ, regardless of the extract dose and time interval, although the responses varied between sexes. In contrast, GEJZ (2 g.kg $\left.{ }^{-1}\right)$ showed antimutagenic activity (anticlastogeny and/or antianeugeny) towards the chemotherapeutic agent DXR $\left(5 \mathrm{mg} \cdot \mathrm{kg}^{-1}\right)$ or NEU (50 mg. $\left.\mathrm{kg}^{-1}\right)$, regardless of the time interval, although once again intersex variation was observed. These findings indicate that compounds in GEZJ can act against DXRinduced mutagenic effects in mouse bone marrow. Such compounds could include $n$-alkanes, triterpenoids [i.e., betulinic acid, alphitolic acid, ursolic acid, ester derivatives of betulinic acid such as 7 $\beta$-(4-hydroxy-benzoyloxy)-betulinic acid, 7 $\beta$-(4-hydro-3-methoxy-benzoyloxy)betulinic acid and 27-(4-hydroxy-3-methoxy-benzoyloxy)-betulinic acid] (Oliveira et al., 2003; Schuhly et al., 1999) and saponins (Alviano et al., 2008). DXR has been reported to induce micronuclei, chromatid and chromosomal aberrations, and DNA single- and double-strand breaks in vitro and in vivo (Bean et al., 1992; Al-Harbi, 1993; Al-Shabanah, 1993; Delvaeye et al., 1993; Jagetia and Nayak, 1996, 2000; Shan et al., 1996; Dhawan et al., 2003; Jagetia and Aruna, 2000). In addition, the major acute toxicity induced by DXR is bone marrow suppression, while the long-term clinical usefulness is limited by a cumulative, dose-dependent, irreversible, chronic cardiotoxicity that manifests itself as congestive heart failure or cardiomyopathy (Van Acker et al., 1995, 2000).

For the PCE/NCE ratio, there were no significant differences between the negative controls $(\mathrm{NaCl})$, the positive control DXR (5 mg.kg $\left.{ }^{-1}\right)$, the GEZJ $\left(0.5 \mathrm{mg} \cdot \mathrm{kg}^{-1}\right)$ group, and mice treated with GEZJ $\left(2 \mathrm{~g}^{\mathrm{kg}} \mathrm{kg}^{-1}\right)+\mathrm{NEU}\left(50 \mathrm{mg} \cdot \mathrm{kg}^{-1}\right)$ or with GEZJ $\left(2 \mathrm{~g}^{\mathrm{kg}}{ }^{-1}\right)+$ DXR $\left(5 \mathrm{mg} \cdot \mathrm{kg}^{-1}\right)$ (Table 1 and Figure 1). For the treatments with GEZJ, there was a significant difference between the dose of $500 \mathrm{mg} \cdot \mathrm{kg}^{-1}$ and the doses of $1.5 \mathrm{~g} \cdot \mathrm{kg}^{-1}$ and $2 \mathrm{~g} \cdot \mathrm{kg}^{-1}$. Although there were no significant intersex differences, the responses did vary with time (24 h vs. $48 \mathrm{~h}$ ). Lower doses of GEZJ (0.5-1 g. $\left.\mathrm{kg}^{-1}\right)$ were not toxic to bone marrow compared to higher doses 


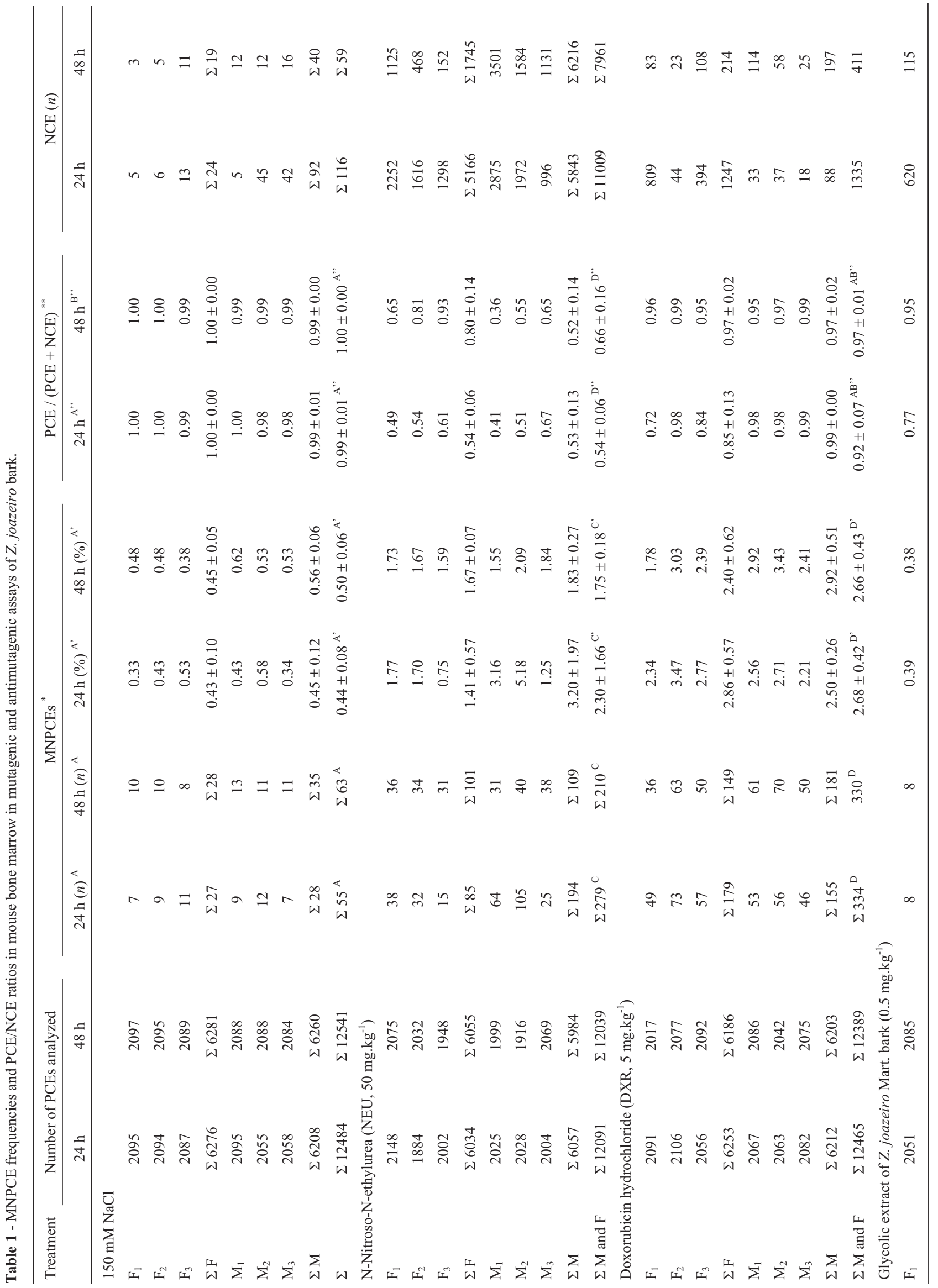




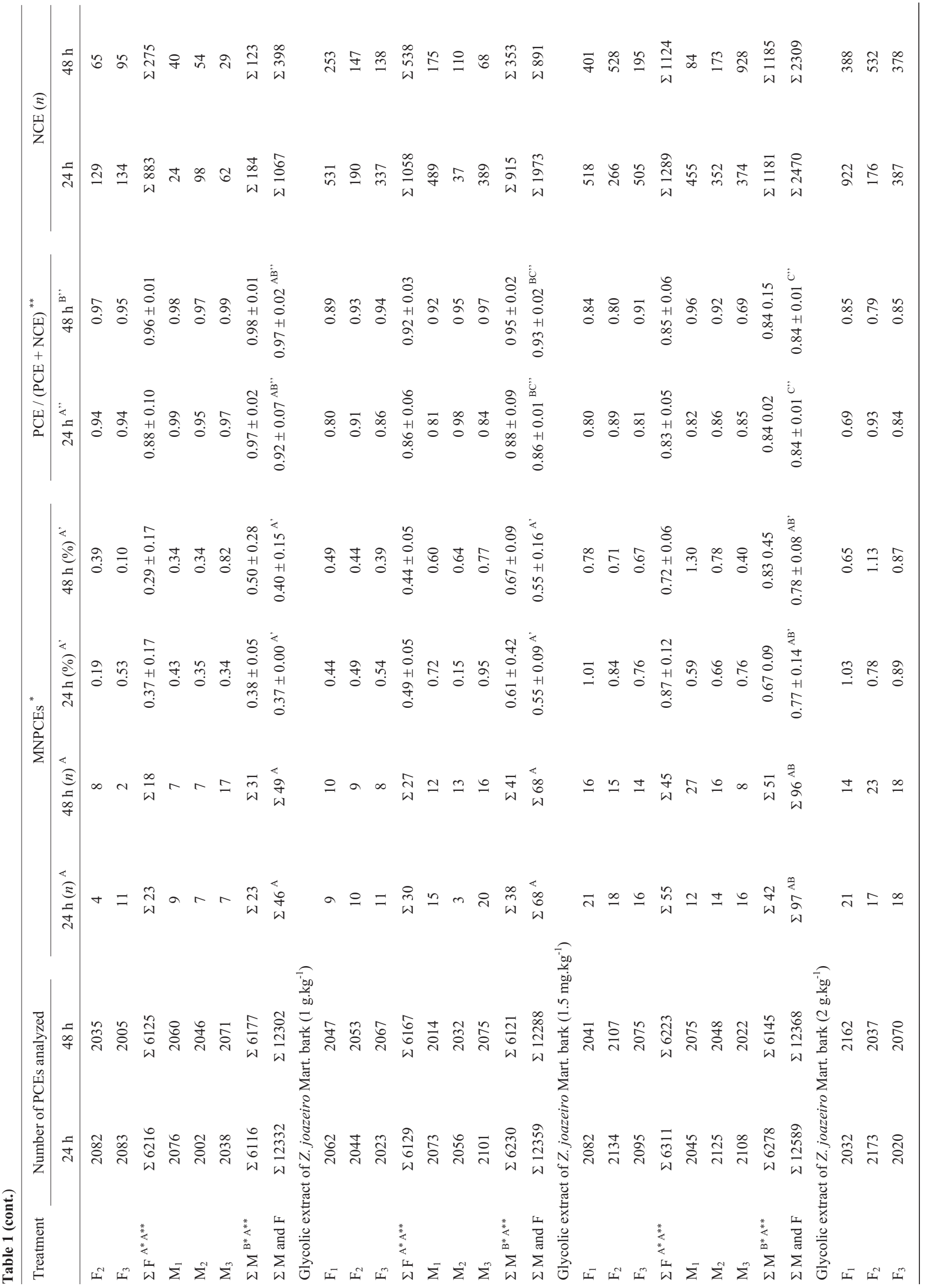




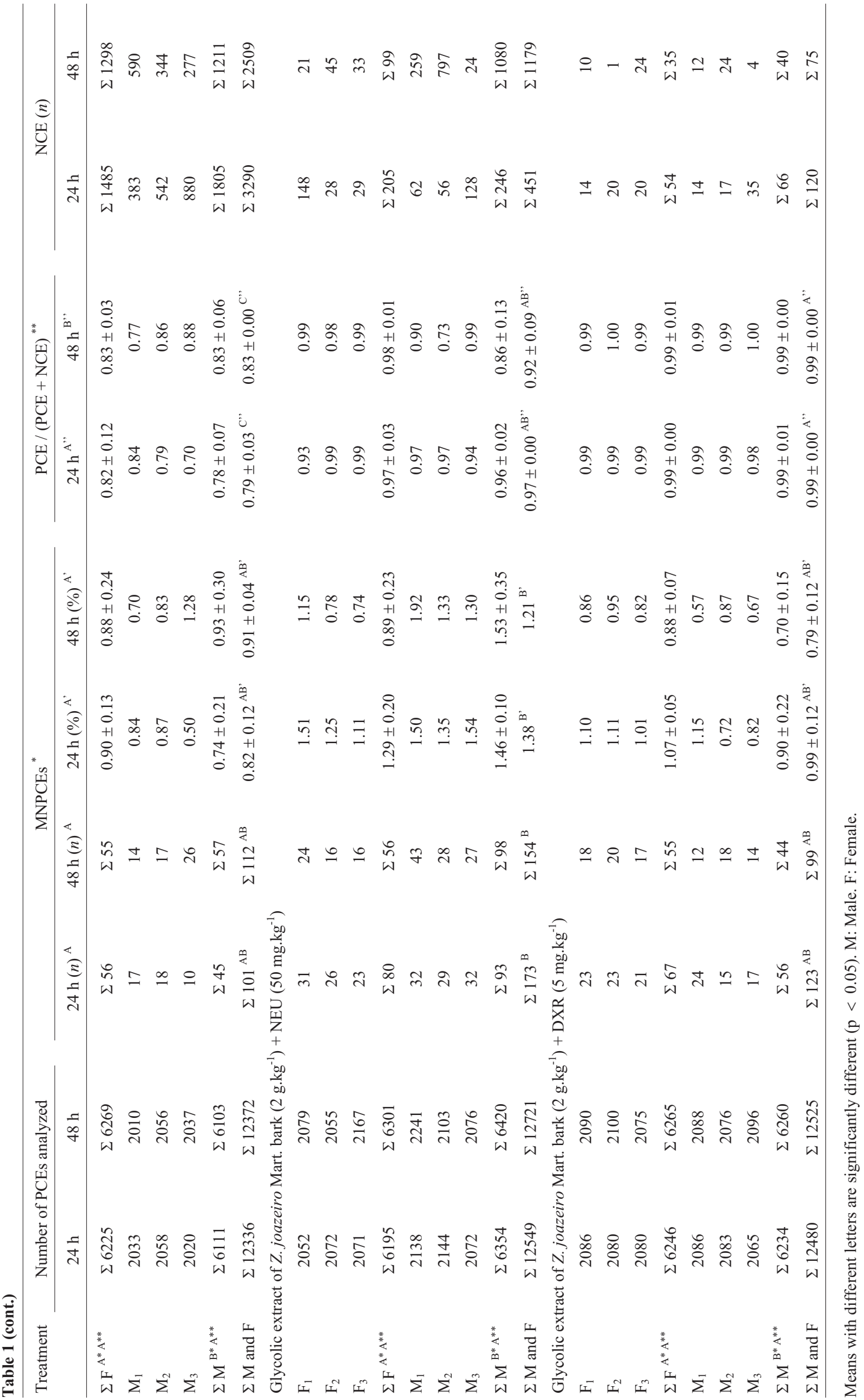


(1.5-2 g.kg-1), regardless of sex, but varied between time intervals. Thus, the PCE/NCE ratio at higher doses was significantly lower than observed in positive the controls treated with NEU. These results suggest the absence of systemic toxicity at GEZJ doses of $0.5-1 \mathrm{~g} \cdot \mathrm{kg}^{-1}$ and moderate toxicity at doses of $1.5-2{\mathrm{~g} . \mathrm{kg}^{-1}}^{-1}$, regardless of mouse gen- der, with variable responses over time (24-48 h). Whereas treatment with GEZJ $\left(2\right.$ g.kg $\left.{ }^{-1}\right)+$ DXR $\left(5 \mathrm{mg} \cdot \mathrm{kg}^{-1}\right)$ significantly reduced the MNPCEs ( $n$ and \%), there was a significant increase in the PCE/NCE ratio with this same treatment, indicating that this combination was not toxic to mouse bone marrow. These results also suggest that the
Distribution of $n(\%)$ MNPCEs

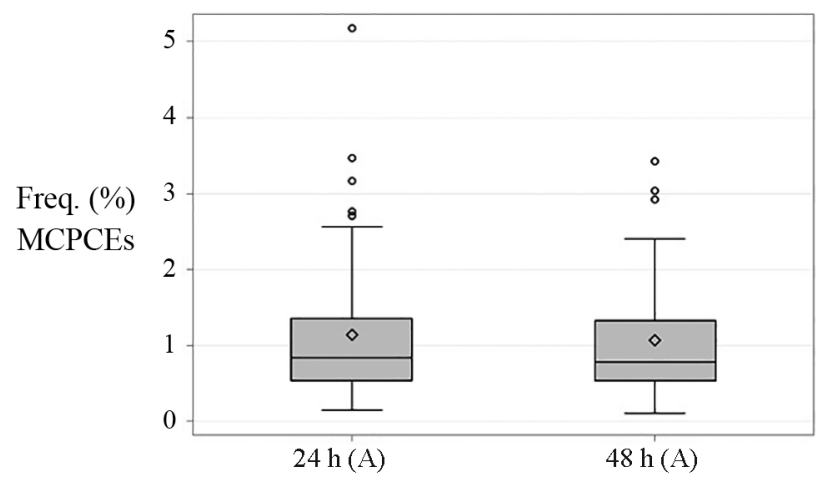

Distribution of $n(\%)$ MNPCEs

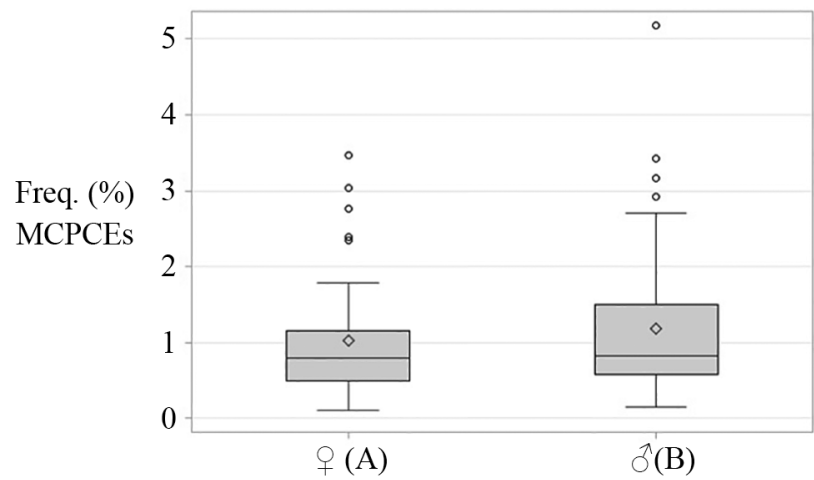

Distribution of $n(\%)$ MNPCEs

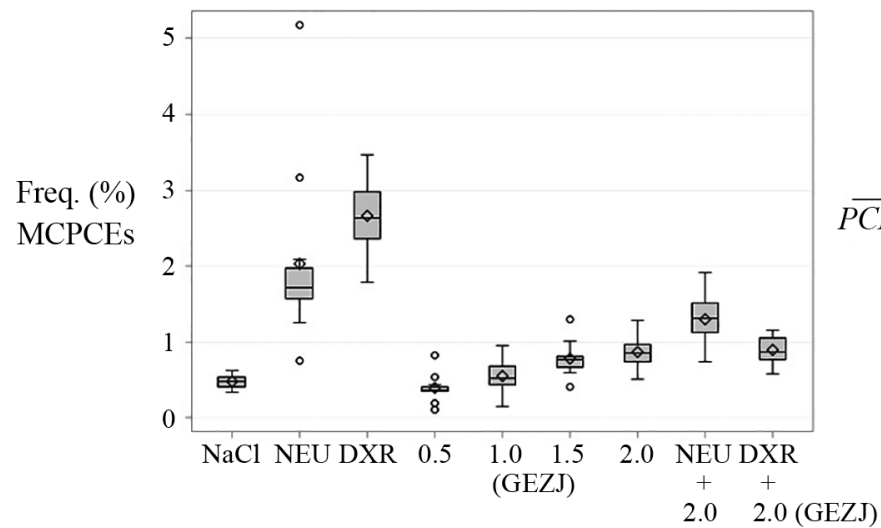

(A)
(C)
(A)
(A) $(\mathrm{AB})(\mathrm{AB})(\mathrm{B})$
$(\mathrm{AB})$

Figure 2 - Box-plots showing the MNPCE frequencies and PCE/NCE ratios in mouse bone marrow in mutagenic and antimutagenic assays of $Z$. joazeiro bark. Means with different letters are significantly different $(\mathrm{p}<0.05)$. NaCl - control group treated with $150 \mathrm{mM} \mathrm{NaCl}, \mathrm{NEU}-\mathrm{N}$-nitroso-N-ethylurea $\left(50 \mathrm{mg} \cdot \mathrm{kg}^{-1}\right)$, DXR - doxorubicin hydrochloride $\left(5 \mathrm{mg} \cdot \mathrm{kg}^{-1}\right)$, GEZJ - Glycolic extract of Z. joazeiro Mart. bark $\left(0.5-2 \mathrm{~g} \cdot \mathrm{kg}^{-1}\right), \mathrm{GEZJ}\left(2 \mathrm{~g} \cdot \mathrm{kg}^{-1}\right)+\mathrm{NEU}$ $\left(50 \mathrm{mg} \cdot \mathrm{kg}^{-1}\right)$ and GEZJ $\left(2 \mathrm{~g} \cdot \mathrm{kg}^{-1}\right)+$ DXR $\left(5 \mathrm{mg} \cdot \mathrm{kg}^{-1}\right)$. 
phytochemical compounds responsible for the moderate toxicity (altered PCE/NCE ratio) of GEZJ $\left(2 \mathrm{~g}^{\mathrm{kg}}{ }^{-1}\right)$ in bone marrow may also have an important role in attenuating the mutagenicity ( $n$ and $\%$ of MNPCE) of DRX $\left(5 \mathrm{mg} \cdot \mathrm{kg}^{-1}\right)$.

The acute toxicity of different plant extracts, including $Z$. joazeiro, has previously been based on doses ( 1 to 4 or $5 \mathrm{~g} / \mathrm{kg}$ ) administered orally to different groups of mice (one dose per mouse, with each group containing eight animals: four males and four females) (Alviano et al., 2008). Behavioral parameters, including convulsion, hyperactivity, sedation, grooming, loss of righting reflex, increased or decreased respiration, and changes in food and water intake were also noted. These animals were observed and weighed over a period of 14 days; no weight loss was detected. Treated mice showed no behavioral alterations and the extract $\mathrm{LD}_{50}$ values ranged from $2.0-3.5 \mathrm{~g} / \mathrm{kg}$. None of the extracts was lethal to mice at the doses tested and the data from the in vivo assays indicated that the extracts had low toxicity (Alviano et al., 2008). The data from the MN assays presented here provides additional information on the systemic toxicity of $Z$. joazeiro in mouse bone marrow based on the PCE/NCE ratio that suggested moderate toxicity of GEZJ at doses of $1.5-2 \mathrm{~g}^{\mathrm{kg}} \mathrm{kg}^{-1}$ that was independent of mouse gender but varied with time (24-48 h).

The PCE/NCE ratio is an indicator of the acceleration or inhibition of erythropoiesis and varies with the scoring interval. A continuous decline in the PCE/NCE ratio may reflect the inhibition of cell division, the killing of erythroblasts, the removal of damaged cells, or dilution of the existing cell pool with newly formed cells (Venkatesh et al., 2007). Several mechanisms may contribute to the cytotoxicity of DXR and MN induction (Gewirtz, 1999), including the intercalation of DXR in cellular DNA (Painter, 1978; Kiyomiya et al., 2001), stabilization of the topoisomerase II-DNA complex (Pommier et al., 1985; Guano et al., 1999), free radical-mediated toxicity caused by redox cycling of the semiquinone radical (Bachur et al., 1979), or the formation of reactive oxygen species by the DXR-iron complex (Eliot et al., 1984; Myers, 1998; Konorev et al., 1999). On the other hand, chemicals such as captopril and desferrioxamine (Al-Harbi, 1993; Al-Shabanah, 1993), $\beta$ carotene and vitamins A, C and E (Lu et al., 1996; Gulkac et al., 2004; Costa and Nepomuceno, 2006), thiol N-acetylcysteine, probucol, lovastatin and hydrophilic flavonoids such as rutin and luteolin (Al-Gharably, 1996; Sadzuka et al., 1997; D'Agostini et al., 1998; Bardeleben et al., 2002) can also reduce DXR-induced MN formation, genotoxicity and cytotoxicity. However, proponents of herbal medicine always claim that mixtures are better than pure chemicals because the dozens of biologically active compounds in plants work together to produce a greater effect than any one chemical on its own (Mackenzie, 2001).

Screening for newer pharmacological agents that can protect normal cells against DXR-induced cumulative toxicity is essential. Many plants widely used in traditional medicine are less toxic than pharmaceutical agents and have recently attracted the attention of researchers around the world. Plants contain many compounds and it is likely that these can provide better protection than a single molecule (Vidhya and Devraj, 1999). The presence of many molecules in plants may be advantageous, as some of them may counteract the toxicity of others so that the net effect may be therapeutically beneficial. For example, the effect of various concentrations $(200,250,300,350$ and 400 $\mathrm{mg} / \mathrm{kg}$ body weight) of Aegle marmelos on DXR-induced mutagenicity in mouse bone marrow was studied (Venkatesh et al., 2007). Mice treated with different concentrations of DXR (5, 10 or $15 \mathrm{mg} \cdot \mathrm{kg}^{-1}$ body weight) showed a dose-dependent elevation in the frequency of PCE and NCE in their bone marrow, and this was accompanied by a DXR-mediated dose-dependent decline in the PCE/NCE ratio. In contrast, the treatment of mice with $A$. marmelos orally once a day for five consecutive days before treatment with DXR significantly reduced the frequency of DXRinduced micronuclei and significantly increased the $\mathrm{PCE} / \mathrm{NCE}$ ratio at all time intervals. This chemoprotective effect may reflect the sum of interactions between different components of this complex mixture. The degree of protection may depend on the individual or collective interaction of components with the genotoxic agent. The plausible mechanisms of action of A. marmelos in protecting against DXR-induced damage included the scavenging of $\mathrm{O}_{2}{ }^{-}, \mathrm{OH}$ and other free radicals, an increase in antioxidant status, restoration of topoisomerase II activity and inhibition of the formation of the DXR-iron complex (Venkatesh et al., 2007). More recently, Alves et al. (2012) evaluated the genotoxic potential of a hydroalcoholic extract of Copaifera lansdorffii Desf. leaves and its influence on the genotoxicity of DXR (MN test) in peripheral blood from Swiss mice. Their finidngs demonstrated that $C$. lansdorffii Desf. was not genotoxic but that the extract significantly reduced the number of micronuclei in DXR-treated mice. The putative antioxidant activity of one or more of the active compounds of $C$. lansdorffii Desf., including two major flavonoid heterosides (quercitrin and afzelin), may explain the effect of this plant on DXR genotoxicity.

\section{Conclusions}

This study used the MN assay to evaluate the mutagenic (clastogeny and/or aneugeny) and antimutagenic activity of an extract of $Z$. joazeiro bark in mouse bone marrow. The $Z$. joazeiro bark extract was not mutagenic at the doses and time intervals tested, although sex-related variation was observed. The antimutagenic effect (anticlastogeny and/or antianeugeny) of Z. joazeiro bark extract against DXR-induced genotoxicity was observed at a high dose of extract $\left(2{\mathrm{~g} . \mathrm{kg}^{-1}}^{-1}\right.$, but was independent of the duration of treatment and animal sex. Low concentrations of GEZJ (0.5-1 g.kg $\left.{ }^{-1}\right)$ were not toxic, regardless of mouse gender and duration of treatment, whereas moderate toxic- 
ity was observed at doses of $1.5-2 \mathrm{~g} . \mathrm{kg}^{-1}$. Together, these findings indicate that phytochemical compounds in $Z$. joazeiro bark can attenuate DRX-induced mutagenicity and that a high dose of extract $\left(2 \mathrm{~g} \cdot \mathrm{kg}^{-1}\right)$ showed no toxicity in the conditions tested here.

Other studies on the genotoxicity and mutagenicity of $Z$. joazeiro extracts are needed to characterize the (anti)genotoxic effects and mechanisms, and to determine the potential health risks of this extract in humans. Such investigations will be useful for implementing strategies related to the use of $Z$. joazeiro bark in chemoprevention.

\section{Acknowledgments}

This research was supported by Rede Mineira de Ensaios Toxicológicos e Farmacológicos de Produtos Terapêuticos (REDE MINEIRA TOXIFAR - 2012) and Fundação de Amparo à Pesquisa do Estado de Minas Gerais (FAPEMIG).

\section{References}

Agência Nacional de Vigilância Sanitária (2010) Farmacopéia Brasileira. Fundação Oswaldo Cruz, Brasília, 545 pp.

Al-Gharably NM (1996) Effect of probucol on the cytological and biochemical changes induced by adriamycin in Swiss albino mice. Res Commun Mol Pathol Pharmacol 94:289-303.

Al-Harbi MM (1993) Effect of captopril on the cytological and biochemical changes induced by adriamycin. Food Chem Toxicol 31:209-212.

Al-Shabanah OA (1993) Inhibition of adriamycin-induced micronuclei by desferrioxamine in Swiss albino mice. Mutat Res 301:107-111.

Alves JM, Munari CC, Neto MABM, Furtado RA, Senedese JM, Bastos JK and Tavares DC (2012) In vivo protective effect of Copaifera langsdorffii hydroalcoholic extract on micronuclei induction by doxorubicin. J Appl Toxicol 33:854860.

Alviano WS, Alviano DS, Diniz CG, Antoniolli AR, Alviano CS, Faria LM, Carvalho MAR, Souza MMG and Bolognese AM (2008) In vitro antioxidant potential of plant extracts and their activities against oral bacteria based on Brazilian folk medicine. Arch Oral Biol 53:545-552.

Ames BN (1983) Dietary carcinogens and anticarcinogens: Oxygen radicals and degenerative diseases. Science 221:12561264.

Bachur NR, Gordon SL, Gee MV and Kon HNR (1979) NADPH cytochrome P-450 reductase activation of quinone anticancer agents to free radicals. Proc Natl Acad Sci USA 76:954-957.

Bardeleben RV, Dunkern T, Kaina B and Fritz G (2002) The HMG-CoA reductase inhibitor lovastatin protects cells from the antineoplastic drugs doxorubicin and etoposide. Int $\mathrm{J}$ Mol Med 10:473-479.

Bean CL, Armstrong MJ and Galloway SM (1992) Effect of sampling time on chromosome aberration yield for 7 chemicals in Chinese hamster ovary cells. Mutat Res 265:31-44.

Beaver BV, Reed W, Leary S, McKiernan B, Bain F, Schultz R, Bennett BT, Pascoe P, Shull E, Cork LC, et al. (2000) Re- port of the American Veterinary Medical Association panel on euthanasia. J Am Vet Med Assoc 218:669-696.

Braga R (1960) Plantas do Nordeste, Especialmente do Ceará. Centro de Divulgação Universitária, Fortaleza, 540 pp.

Cartaxo SL, Sousa MMA and Albuquerque UP (2010) Medicinal plants with bioprospecting potential used in semi-arid northeastern Brazil. J Ethnopharmacol 13:326-342.

Chandrasekaran CV, Sundarajan K, Gupta A, Srikanth HS, Edwin J and Agarwal A (2011) Evaluation of the genotoxic potential of standardized extract of Glycyrrhiza glabra (GutGard $^{\mathrm{TM}}$ ). Regul Toxicol Pharmacol 61:373-380.

Chorilli M, Brizante AC, Rodrigues CA and Salgado HRN (2007) Aspectos gerais em sistemas transdérmicos de liberação de fármacos. Rev Bras Farm 88:7-13.

Collaborative Study Group for the Micronucleus Test (CSGMT) (1986). Sex differences in the micronucleus test. Mutat Res 172:151-163.

Costa WF and Nepomuceno JC (2006) Protective effects of a mixture of antioxidant vitamins and minerals on the genotoxicity of doxorubicin in somatic cells of Drosophila melanogaster. Environ Mol Mutagen 47:18-24.

Cruz GL (1985) Dicionário das Plantas Úteis do Brasil. Editora Civilização Brasileira S.A., Rio de Janeiro, 405 pp.

Cruz MCS, Santos AM, Barbosa Jr AM, de Melo DLFM, Alviano CS, Antoniolli AR, Alviano DS and Trindade RC (2007) Antifungal activity of Brazilian medicinal plants involved in popular treatment of mycoses. J Ethnopharmacol 111:409412.

D’Agostini F, Bagnasco M, Giunciuglio D, Albini A and de Flora S (1998) Inhibition by oral $\mathrm{N}$-acetylcysteine of doxorubicin-induced clastogenicity and alopecia, and prevention of primary tumors and lung micrometastases in mice. Int $\mathrm{J}$ Oncol 3:217-224.

Delvaeye M, Verovski V, De Neve W and Storme G (1993) DNA breakage, cytotoxicity, drug accumulation and retention in two human ovarian tumor cell lines AZ224 and AZ364 treated with adriamycin, modulated by verapamil. Anticancer Res 13:1533-1538.

Dhawan A, Kayani MA, Parry JM, Parry E and Anderson D (2003) Aneugenic and clastogenic effects of doxorubicin in human lymphocytes. Mutagenesis 18:487-490.

Eliot H, Gianni L and Myers C (1984) Oxidative destruction of DNA by the adriamycin-iron complex. Biochemistry 5:928-936.

Gewirtz DA (1999) A critical evaluation of the mechanisms of action proposed for the antitumor effects of the anthracycline antibiotics adriamycin and daunorubicin. Biochem Pharmacol 57:727-741.

Guano F, Pourquier P, Tinelli S, Binaschi M, Bigioni M, Animati F, Manzini S, Zunino F, Kohlhagen G, Pommier Y, et al. (1999) Topoisomerase poisoning activity of novel disaccharide anthracyclines. Mol Pharmacol 56:77-84.

Gulkac MD, Akpinar G, Ustun H and Ozon KA (2004) Effects of vitamin A on doxorubicin-induced chromosomal aberrations in bone marrow cells of rats. Mutagenesis 19:231-236.

Indart A, Viana M, Clapés S, Izquierdo L and Bonet B (2007) Clastogenic and cytotoxic effects of lipid peroxidation products generated in culinary oils submitted to thermal stress. Food Chem Toxicol 45:1963-1967.

Jagetia GC and Aruna R (2000) Correlation between cell survival and micronuclei-induction in HeLa cells treated with adria- 
mycin after exposure to various doses of gamma-radiation. Toxicol Lett 115:183-193.

Jagetia GC and Nayak V (1996) Micronuclei-induction and its correlation to cell survival in HeLa cells treated with different doses of adriamycin. Cancer Lett 110:123-128.

Jagetia GC and Nayak V (2000) Effect of doxorubicin on cell survival and micronuclei formation in HeLa cells exposed to different doses of gamma-radiation. Strahlenther Onkol 176:422-428.

Kiyomiya K, Matsuo S and Kurebe M (2001) Differences in intracellular sites of action of adriamycin in neoplastic and normal differentiated cells. Cancer Chemother Pharmacol 47:51-56

Konorev EA, Kennedy MC and Kalyanaraman B (1999) Cellpermeable superoxide dismutase and glutathione peroxidase mimetics afford superior protection against doxorubicininduced cardiotoxicity: The role of reactive oxygen and nitrogen intermediates. Arch Biochem Biophys 368:421-428.

Konstantoupoulou I, Vassilopoulov L, Maviaganitsipido U and Scouras ZG (1992) Insecticidal effects of essential oils. A study of the effects of essential oils extracted from eleven Greek aromatic plants on Drosophila auraria. Experientia 48:616-619.

Leal ICR, Santos KRN, Itabaiana Jr I, Antunes OAC, Porzel A, Wessjohann L and Kuster RM (2010) Ceanothane and lupane type triterpenes from Zizyphus joazeiro - An antistaphylococcal evaluation. Planta Med 76:47-52.

Lu HZ, Geng BQ, Zhu YL and Yong DG (1996) Effects of beta-carotene on doxorubicin-induced cardiotoxicity in rats. Zhongguo Yao Li Xue Bao 17:317-320.

Mackenzie D (2001) Complementary medicine, a special report. Swallow it whole. New Sci 2292:38-40.

Mateuca R, Lombaert N, Aka PV, Decordier I and Kirsch-Volders M (2006) Chromosomal changes: Induction, detection methods and applicability in human biomonitoring. Biochimie $88: 1515-1531$.

Myers C (1998) The role of iron in doxorubicin-induced cardiomyopathy. Semin Oncol 25:10-14.

Nunes PHM, Marinho LC, Nunes MLRL and Soares EO (1987) Antipyretic activity of an aqueous extract of Zizyphus joazeiro Mart. (Rhamnaceae). Braz J Med Biol Res 20:599-601.

OECD (1997a) Guidelines for the Testing of Chemicals: Bacterial reverse mutation test. Organisation for Economic Cooperation and Development, Paris, Guideline 471, $11 \mathrm{pp}$.

OECD (1997b) Guideline for the Testing of Chemicals: In vitro mammalian chromosome aberration test. Organisation for Economic Cooperation and Development, Paris, Guideline 473, $14 \mathrm{pp}$.

OECD (1997c) Guideline for the Testing of Chemicals: Mammalian erythrocyte micronucleus test. Organisation for Economic Cooperation and Development, Paris, Guideline 474, $10 \mathrm{pp}$.

Oliveira AFM, Meirelles ST and Salatino A (2003) Epicuticular waxes from caatinga and cerrado species and their efficiency against water loss. An Acad Bras Cienc 75:431-439.
Painter RB (1978) Inhibition of DNA replicon initiation by 4-nitroquinoline 1-oxide, adriamycin, and ethyleneimine. Cancer Res 38:4445-4449.

Pommier Y, Schwartz RE, Zwelling LA and Kohn KW (1985) Effects of DNA intercalating agents on topoisomerase II induced DNA strand cleavage in isolated mammalian cell nuclei. Biochemistry 24:6406-6410.

Purves D, Harvey C, Tweats D and Lumley CE (1995) Genotoxity testing: Current practices and strategies used by the pharmaceutical industry. Mutagenesis 10:297-312.

Ribeiro LR (2003) Teste de micronúcleo em medula óssea de roedor in vivo. In: Ribeiro LR, Salvadori DMF and Marques EK (eds) Mutagênese Ambiental. Ulbra, Canoas, pp 173198.

Sadzuka Y, Sugiyama T, Shimoi K, Kinae N and Hirota S (1997) Protective effect of flavonoids on doxorubicin-induced cardiotoxicity. Toxicol Lett 92:1-7.

Schmid W (1976) Chemical mutagens. In: Hollender A (ed) The Micronucleus Test for Cytogenetic Analysis. Plenum Press, New York, pp 31-53.

Schuhly W, Heilmann J, Calis I and Sticher O (1999) New triterpenoids with antibacterial activity from Zizyphus joazeiro. Planta Med 65:740-743.

Shan K, Lincoff AM and Young JB (1996) Anthracycline-induced cardiotoxicity. Ann Inter Med 125:47-58.

Silva CR, Vieira PM, Santos SC and Chen-Chen L (2011) Assessment of Duguetia furfuracea genotoxic and cytotoxic activity in bacteria and mice. An Acad Bras Ciênc 84:149-156.

Tavares W (1996) Manual de Antibióticos e Quimioterápicos Anti-Infecciosos - Introdução ao Estudo dos Antimicrobianos. Atheneu, Rio de Janeiro, 792 pp.

UNESCO (1978) Comissão de Ética no Uso de Animais, Declaração Universal dos Direitos dos Animais (UNESCO), Bruxelas, Bélgica, 2 pp.

Van Acker SA, Kramer K, Grimbergen JA, Van Den Berg DJ, Van Der Vijgh WJ and Bast A (1995) Monohydroxyethylrutoside as protector against chronic doxorubicin-induced cardiotoxicity. Br J Pharmacol 115:1260-1264.

Van Acker FA, Van Acker SA, Kramer K, Haenen GR, Bast A and Van Der Vijgh WJ (2000) 7-Monohydroxyethylrutoside protects against chronic doxorubicin-induced cardiotoxicity when administered only once per week. Clin Cancer Res 6:1337-1341

Varanda EA (2006) Atividade mutagênica de plantas medicinais. Rev Ciênc Farm Básica Apl 27:1-7.

Venkatesh P, Shantala B, Jagetia GC, Rao KK and Baliga MS (2007) Modulation of doxorubicin-induced genotoxicity by Aegle marmelos in mouse bone marrow: A micronucleus study. Integr Cancer Ther 6:42-53.

Vidhya N and Devraj SN (1999) Antioxidant effect of eugenol in rat intestine. Ind J Exp Biol 37:1192-1195.

Zambrano MA, Targa HJ and Rabello-Gay MN (1982) Physiological saline solutions as a useful tool in micronucleus and metaphase slide preparations. Stain Technol 57:48-49.

Associate Editor: Daisy Maria Fávero Salvadori

License information: This is an open-access article distributed under the terms of the Creative Commons Attribution License, which permits unrestricted use, distribution, and reproduction in any medium, provided the original work is properly cited. 